\title{
Synthesis and characterization of nano- amendment for effective remediation of soil acidity
}

\section{CH BHARGAVA RAMI REDDY AND K.S. SUBRAMANIAN}

Received : 07.01.2016; Revised : 20.03.2016; Accepted : 16.04 .2016

\section{Corresponding author :} CH BHARGAVA RAMI REDDY, Department of Soil Science and Agricultural Chemistry, Tamil Nadu Agricultural University, COIMBATORE (T.N.) INDIA

Email: bhargava.basf@gmil.com

Co-authors :

K.S. SUBRAMANIAN, Department of Nano Science and Technology, Tamil Nadu Agricultural University, COIMBATORE (T.N.) INDIA

\section{Summary}

Industrialization and climate change had increased soil acidity which deteriorated the soil health and reduced crop productivity through release of toxic concentration hydrogen and aluminium, manganese and iron. Acid soils $(\mathrm{pH}<5.5)$ are extensively found in region of high rainfall, temperature and hilly region. Liming of acid soils the changes ( $\mathrm{pH} 5.5$ to 6.5), rectifies adverse effects and also improves the soil fertility. But large quantity of lime used (7.2 tons per acre). In order to optimize the rate of lime nano technological approach was used. Naturally available micro-size conventional calcium carbonate particles were used for synthesis of nano crystals through physical method of top down approach, using high energy ball milling (HEBM) with different hours and encapsulated with non-ionic surfactant (1\% chitosan). It produced uniform nano sized particles (nano-lime), which were characterised using particle size analyser (approximately $115-120 \mathrm{~nm}$ ), zeta potential $(-50 \mathrm{mV})$, powder X-ray diffraction (d spacing 3.13). It confirmed that presence of Ca and Mg with Raman Shifts $\left(713,1086 \mathrm{~cm}^{-1}\right)$ and Fourier transform infrared spectroscopy $\left(844.7 \mathrm{~cm}^{-1}\right)$. Shape and structure was observed through scanning electron microscopy (SEM) and transmission electron microscopy (TEM). Synthesized of calcium carbonate nano crystalline particles were environment friendly. Reduced particle size and increased surface area where offered an opportunity for reclamation of soil acidity as an amendment and can be scaled up for agricultural production.

Key words : Acid soils, Lime, Nanotechnology, High energy ball milling

How to cite this article : Reddy, Ch Bhargava Rami and Subramanian, K.S. (2016).Synthesis and characterization of nano-amendment for effective remediation of soil acidity. Asian J. Soil Sci., 11 (1) : 51-57 : DOI : 10.15740/HAS/AJSS/11.1/51-57. 